\title{
FACTORS AFFECTING CONDOM USE AMONG JUNIOR SECONDARY SCHOOL PUPILS IN SOUTH AFRICA
}

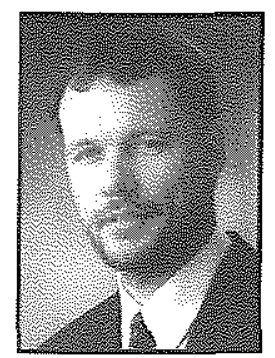

\author{
Prof. Karl Peltzer
}

Department of Psychology

University of the North

\section{ABSTRACT}

The aim of the study is to investigate factors affecting condom use among junior Secondary School pupils in South Africa. The sample included 446 Grade 10 Secondary school pupils, 200 (44.8\%) males and 246 (55.2\%) females within the age range of 10 to 30 years ( $M$ age 16.6 years, $S D=2.5$ ) from three rural schools in one region of the Northern Province in South Africa. Main outcome measures included sexual activity and condom use (12 items), source of 'condom' information (12 items), knowledge of correct condom use (10 items), a 16-item AIDS Health Belief Scale and a 28-item Condom Use Self-Efficacy Scale. Results indicated that more than half of the sexually active males $(56 \%)$ and almost one third (18.6\%) of the females reported, have never used condoms. About $80 \%$ levels of correct answers were found for the items of "protection against AIDS" and "expiry date of condoms". About 30\% of the females were not aware that condoms offer protection against AIDS and sexually transmitted diseases. The AIDS Health Belief scale was related to past and current condom use as well as to self-efficacy in condom use but not with condom use intentions. Self-efficacy of condom use was not related to past, current and future condom use. Subjective norms about condoms were found to predict condom use intention and AIDS susceptibility predicted lifetime condom use and condom self-efficacy. Findings have relevant implications and are discussed in the context of developing an educational or intervention programme.

\section{OPSOMMING}

Die doel van die navorsing is om faktore na te vors wat die gebruik van kondome deur leerlinge in die junior fase van sekondêre skole in Suid-Afrika beinvloed. Die steekproef bestaan uit 446 graad 10 leerlinge waarvan 200 manlik (44.8\%) en 246 vroulik (55.2\%) is. Die ouderdomme wissel van 10 tot 30 jaar (gemiddeld 16.6 jaar, standaardafwyking 2.5 jaar). Leerlinge is afkomstig van drie plattelandse skole uit een streek van die Noordelike Provinsie in Suid-Afrika. Die volgende faktore is gemeet: Seksuele aktiwiteite en die gebruik van kondome (12 items), kennis van die korrekte gebruik van kondome (10 items), "Aids Health Belief Scale" (16 items) en "Condom Use Self-Efficacy Scale" (28 items). Die resultate dui daarop dat meer as die helfte van seksueel aktiewe manlike proefpersone (56\%) en bykans een derde van die vroulike proefpersone (18.6\%) nog nooit kondome gebruik het nie. Ongeveer $30 \%$ van die vroulike proefpersone was nie daarvan bewus dat kondome teen Vigs en seksueel oordraagbare siektes beskerming bied nie. Ongeveer $80 \%$ korrekte antwoorde is gerapporteer vir die items "Protection against Aids" en "Expiry date of condoms". Die "Aids Health Belief Scale" meet die gebruik van kondome in die verlede en die hede asook die effektiwiteit van die gebruik van kondome maar nie die intensies met die gebruik daarvan nie. Die effektiwiteit van die gebruik van kondome verwys nie na die gebruik in die verlede, hede of toekoms nie. Subjektiewe norms oor die gebruik van kondome is gebruik om die intensies met die gebruik van kondome te voorspel sowel as die effektiwiteit van die gebruik van kondome en die voorspelde vatbaarheid vir lewenslange gebruik van kondome. Die bevindinge het implikasies wat relevant is en word bespreek in die konteks van die ontwikkeling van opvoedkundige en intervensie programme.

\section{INTRODUCTION AND PROBLEM STATEMENT}

Condoms are an integral part of STD and HIV/AIDS prevention, and their use has increased significantly over the past decade. Correct use of them reduces the risk of HIV transmission by almost 100 percent. Therefore, condom promotion has received considerable attention in the fight against the AIDS pandemic (World Health Organisation, 1995:5-10). This is particularly important in sub-Saharan Africa where HIV transmission is mainly through sexual contact. Yet condom use is among the most difficult issues to address in designing programmes to reduce the sexual transmission of HIV in Africa. Campbell (1997:186) surmises for sub-Saharan Africa that negative attitudes toward condom use are often based on cultural factors, e.g. the desire for children and female sexual compliance as ways to achieve economic status.

Lule and Gruer (1991:15) found among Ugandan 
students that only a minority saw the condom as an effective preventive method against HIV/AIDS: most saw it as unsafe or an encouragement to promiscuity. Condoms had been used by $35 \%$ of men and $24 \%$ of women but were currently always used by only $9 \%$ of men and $11 \%$ of women. The condom was approved of by only one quarter of respondents. Kenyan university students appear to have negative attitudes toward condoms in general and do not see them as a viable tool in fighting AIDS (Sindiga \& Luhando, 1993:713). Kidan and Azeze (1995:9) surveyed condom use among Ethiopian college students and reasons given for not using condoms included: unavailability $(44.3 \%)$, partner trust $(43 \%)$, shortage of condoms $(8 \%)$, and partner's disagreement $(5.1 \%)$. In South Africa, aversion to condom use is the dominant theme, although explanations for this vary; cultural beliefs are also a barrier to condom use in South Africa, where many people consider it essential that the sperms of the men actually enters the woman (Gould, 1993:132f.).

Research also shows that the spread of HIV/AIDS is on the increase. It is expected that the prevalence of AIDS will reach about $27 \%$ of the sexually active population in South Africa by the year 2010(Webb, 1997:214).

\section{RESEARCH PROBLEM AND PURPOSE/AIM OF THE RESEARCH}

Literature indicates that factors affecting condom use are a range of situational, interpersonal and structural factors such as knowledge about AIDS, behavioural intention, perceived susceptibility, perceived barriers, self-efficacy, and demographic factors (e.g. BasenEngquist, 1992:120; Bandawe \& Foster, 1996:223; Manderson, Tye \& Rajanayagam, 1997:5ff.). Edem and Harvey (1994/95:3) found among Nigerian University students that condom benefit beliefs, condom barrier beliefs, cues to action, knowledge, and male gender were significant predictors of past condom use. Perceived barriers to condom use, perceived benefits of use, and male gender were significant predictors of intentions to use condoms. Such findings have important implications for the design of interventions to increase condom use among secondary school pupils and young adults. Abrahim, Sheeran, Abrams and Spears (1996:641) have noted that the health belief model measures did not account for significant proportions of variance in consistency of condom use or mediate the effects of prior sexual experience or demographic measures among adolescents in the UK. Abraham, Rubaale and Kipp (1995:155) found among secondary school students in Uganda that approximately a third of the variance in men and women's condom use self-efficacy, half the variance in women's condom use intentions, and a quarter of the variance in the men's condom use intentions were accounted for by specific variables.

In addition, findings suggest that prevention efforts to promote condom use must be gender as well as culturespecific if they are to be effective (Harvey, Beckman \& Wright, 1996/97:139).

There is a lack of studies on factors affecting condom use among younger age groups despite the fact that HIV infection rates have become increasingly higher among adolescents. Therefore this study aims at investigating different factors influencing condom use among junior secondary school pupils in South Africa.

\section{METHODS}

\section{Sample and procedure}

The sample consisted of 446 Grade 10 , Secondary School pupils chosen from the total Grade 10 population throughout one region in the Northern Province. The participants were randomly sampled within grade-level and gender, using class registers. There were no dropouts in this sample. The pupils were $200(44.8 \%)$ males and $246(55.2 \%)$ females within the age range of 10 to 30 years ( $\mathrm{M}$ age $16.6 \mathrm{yr}$., $\mathrm{SD}=2.5$ ). More than 84 percent came from a rural background and 15.4 percent came from an urban background.

In this study only those cases were analysed who had had a sexual experience. These were in total 149,70 female and 79 male. Therefore in the following discussion the sample size will only include those who had had a sexual experience. Most were Northern Sotho $(106,71.1 \%)$, followed by Tsonga $(23,15.4 \%)$, Venda $(7,4.7 \%)$, Ndebele $(6,4 \%)$, and others $(7,4.8 \%)$.

The students were clearly informed that the purpose of the survey was to find out about the use and knowledge of the condom and that their responses would be totally anonymous. Each student was requested to complete the questionnaire or indicate that he or she did not wish to do so. Permission was obtained from the parents, where necessary, the Department of Education, and the principals of the respective schools.

\section{Data collection and analysis}

The instrument, which was essentially a questionnaire, was pre-tested on 15 male and 15 female pupils, who did not form part of the final sample. The final questionnaire consisted of questions about:

- Biographic data (6 items).

- Sexual activity and condom use (12 items) (see Table 1).

- Knowledge of correct condom use (10 items) (see Table 2). Knowledge about correct use of condoms was evaluated as per standard guidelines for use of condoms (Sharma, Dave \& Sharma et al. 1997:710; World Health Organisation, 1990:5ff). There were ten closed questions, each with one possible correct answer (e.g. when to put on a condom, how to use it correctly, how and when to take it off, the use of 
lubricants, etc.) and for each correct answer one point was awarded; the total points comprised the knowledge score range from 0 to 10.

- Source of 'condom' information (12 items) (see Table 3).

- Condom use intention (when having sex next time with a new partner) ( 1 item) (from $-2=$ strongly agree to $+2=$ strongly disagree).

- Behavioural norm to use condoms (3 items), such as "Do you and your friends talk about using condoms?" (rated $1=$ Yes, $-\mathrm{I}=$ No, $0=$ Don't know).

- Attitudes towards condoms ( 3 items), such as "It is a good idea for me to use condoms" (rated from $-2=$ strongly agree to $+2=$ strongly disagree).

- Normative beliefs about condoms ( 3 items), such as "My parents think I should use condoms" (rated from $-2=$ strongly agree to $+2=$ strongly disagree).

- Subjective norms about condoms "Most people who are important to me think I should use condoms" (1 item) (rated from $-2=$ strongly agree to $+2=$ strongly disagree).

- A 16-item AIDS Health Belief Scale (AHBS), developed by Zagumny and Brady (1998:173ff.), to measure the four components of the Health Belief Model (HBM): perceived susceptibility to disease, perceived severity of a specific disease, perceived benefits of preventive behaviour, and barriers to preventive behaviour. Scaling involved the use of a 6-point Likert type scale with responses of "strongly agree" weighted 6 and "strongly disagree" weighted 1. For all sub-scales, higher scores represent a greater amount of that belief. Past research on the predictive utility of the HBM for HIV preventive behaviours suggests that perceived susceptibility, perceived benefits, and perceived barriers are the strongest predictors of HIV preventive behaviours. Cronbach alpha as well as split-half reliability coefficients for the AIDS Health Belief Scale were .89 and .83 for this sample.

- A 28-items Condom Use Self-Efficacy Scale (CUSES). Self-efficacy refers to the strength of an individual's belief in his own ability to respond to novel or difficult situations and to deal with any associated obstacles or setbacks. Examples of statements are: (i) I feel confident in my ability to put a condom on myself or my partner, (ii) If my partner and I were to try to use a condom and did not succeed, I would feel embarrassed to try to use one again (e.g. not being able to unroll condom, putting it on backwards, or awkwardness), or (iii) I feel confident that I could use a condom with a partner without 'breaking the mood'. Each item has a 5point strongly disagree (scored as 0 ) to strongly agree (scored as 4) response format. After reversing negatively worded items, the scores are added up yielding a total score ranging from 0 to 112 , with higher scores indicating greater condom selfefficacy (Brafford \& Beck, 1991:219ff.). Cronbach alpha as well as split-half reliability coefficients for the Condom Use Self-Efficacy Scale was .79 and .71 for this sample.

Data analysis techniques used included Chi-square, Ttest, correlations and stepwise multiple regression analysis using the Social Sciences Statistical Package (SPSS version 8.0).

\section{RESULTS}

\section{Sexual parameters}

About one year after puberty, both male ( $M=14.9$ years $)$ and females $(M=15.6$ years $)$ had engaged in sex. More than half (58\% for boys and $71 \%$ for girls) knew about condoms prior to first sex, but only $25.3 \%$ of the males and $71.4 \%$ of the females used condoms on first sex. At a mean age of 16.6 years $40.2 \%$ of the males and $23.9 \%$ of the females had already had more than one sex partner. Males had significantly more lifetime sex partners and engaged earlier in a relationship in sex than females. Half the males $(50 \%)$ felt that the normal duration of a relationship before sex is less than 7 days whereas $34.8 \%$ of the females stayed in a relationship for more than a month before having sex. More than half of the sexually active males $(56 \%)$ and almost one third $(18.6 \%)$ of the females reported never having used condoms. Males had sex more often under the influence of alcohol and had a greater history of sexually transmitted disease (see Table 1).

Table 1: Sexual characteristics by gender in percent (or in mean if indicated)

\begin{tabular}{|c|c|c|c|}
\hline Variable & $\begin{array}{l}\text { Male } \\
(n=79)\end{array}$ & $\begin{array}{l}\text { Female } \\
(n=70)\end{array}$ & $\begin{array}{l}X^{2} \\
\text { (1) T-test }\end{array}$ \\
\hline 1. Onset of puberty (mean age and SD) & $13.0(4.5)$ & $14.5(1,8)$ & $-2.344^{\circ}(1)$ \\
\hline 2. Age of frst vaginal sex (mean age and SD) & $14.9(7.9)$ & $15.6(2.6)$ & $-1.76(1)$ \\
\hline 3. Knowledge of condom priar to first sex & 58.2 & 71.4 & $6.344^{*}$ \\
\hline 4. Used condom on first sex & 25.3 & 60.0 & $22.258^{* 2 \times x}$ \\
\hline \multicolumn{4}{|l|}{ 5. No lifetime sex partners: } \\
\hline 1 & 43.9 & 61.2 & \\
\hline $2-5$ & 40.2 & 23.9 & $9.426^{*}$ \\
\hline $6-10$ & 06.1 & 03.0 & \\
\hline$>10$ & 09.8 & 11.9 & \\
\hline \multicolumn{4}{|l|}{6 . Normal duration of relationship before sex: } \\
\hline$<7$ days: & 50.0 & 28.8 & \\
\hline$>1-4$ weeks: & 36.6 & 36.4 & $17.466^{* * *}$ \\
\hline$>1$ months: & 09.8 & 34.8 & . \\
\hline 7. Has a steady partner & 25.3 & 15.7 & 4.323 \\
\hline 8. Ever used condom & 43.0 & 71.4 & $14.807^{*+*}$ \\
\hline \multicolumn{4}{|l|}{ 9. Condom use with last sex partner: } \\
\hline Never: & 55.6 & 42.4 & \\
\hline Iiregular: & 18.5 & 31.8 & \\
\hline Regular: & 24.7 & 15.2 & $11.380^{*}=$ \\
\hline Eveny time: & 01.2 & 10.6 & \\
\hline 10. Had sex under infuence of alcohol & 40.0 & 24.1 & $5.920^{\circ}$ \\
\hline 11. Had an STD & 400 & 30.4 & 2.800 \\
\hline 12. Know someone with HIV/AIDS & 12.7 & 34.3 & $10.622^{*+5}$ \\
\hline
\end{tabular}




\section{Condom knowledge}

Table 2 indicates the knowledge about correct condom use among the participants.

Table 2: Knowledge about correct condom use by gender in percent

\begin{tabular}{|c|c|c|c|}
\hline Ttems & $\frac{\frac{\mathbb{W}}{\mathbb{E}}}{\Sigma}$ & $\frac{\frac{1}{5}}{\sum_{0}^{\circ}}$ & $x^{2}$ \\
\hline 1. Do condoms offer protection against AIDS? & 94.9 & 74.3 & $4.825^{\star}$ \\
\hline 2. Do condoms have an expiry date? & 88.6 & 77.1 & $4.093^{*}$ \\
\hline 3. Do condoms offer protection against STD's? & 91.1 & 65.7 & $5.142^{*}$ \\
\hline 4. Should a condom be checked for leaks and holes? & 84.8 & 60.0 & $11.352^{*+}$ \\
\hline 5. Can a condom be re-used? $(3$ & 82.3 & 52.9 & $9.872^{* \star}$ \\
\hline $\begin{array}{l}\text { 6. Should a condom be put on before any contact with the } \\
\text { vagina? }\end{array}$ & 79.7 & 52.9 & $7.798^{\star \star}$ \\
\hline $\begin{array}{l}\text { 7. Should a condom be unrolled before being put on the } \\
\text { penis? (3) }\end{array}$ & 74.7 & 51.4 & $5.297^{*}$ \\
\hline $\begin{array}{l}\text { 8. Can an oil-based lubricant (e.g. oil, vaseline, cold } \\
\text { cream) be used with a condom? } 8\end{array}$ & 64.6 & 54.3 & .460 \\
\hline $\begin{array}{l}\text { 9. Is it essential for a person using a condom to withdraw } \\
\text { his penis immediately after ejaculation? }\end{array}$ & 63.3 & 55.7 & .117 \\
\hline $\begin{array}{l}\text { 10. Is it alright to put on a condom just betore ejaculation? } \\
\text { (8) }\end{array}$ & 43.0 & 42.9 & .165 \\
\hline
\end{tabular}

\section{B reverse scored}

About $80 \%$ levels of correct answers were found for the items of "protection against AIDS" and "expiry date of condoms". About $30 \%$ of the females were not aware that condoms offer protection against AIDS and sexually transmitted diseases. The most common mistakes with respect to condom use were ignorance about the correct moment to put on a condom, inability to put on a condom properly, when to take off a condom, and the use of oil-based lubricants, in this order. Generally, males had significantly more correct knowledge about condom use than females.

\section{Source of 'condom' information}

More than $80 \%$ of the pupils indicated that their sources of 'condom' information was, in descending order of importance, radio, television, education talks, newspaper, social/health magazines, posters and pamphlets, health care provider, and been given free condoms. There was only a gender difference for (12: "Been given free condoms") $(p<005)$. "Social/Health magazines $^{\circ}\left(\mathrm{r}=.237^{* *}\right)$ and 'Been given free condoms ${ }^{\circ}$ $\left(\mathrm{r}=313^{* *}\right)$ was significantly associated with condom use with the last partner. Correct condom use knowledge was associated with the following sources of 'condom' information: social/religious organisation, health care provider, and posters and pamphlets, in that order (see Table 3).
Table 3: Source of condom information by gender, in percent, and in relation to correct condom use knowledge

\begin{tabular}{|l|l|l|l|}
\hline & Male & Fe* & Condom knowledge \\
\hline 1. Radio & & male & score \\
\hline 2. Television & & & $r$ \\
\hline 3. Education talks & 96.3 & 92.5 & .124 \\
\hline 4. Newspapers & 89.9 & 89.6 & .099 \\
\hline 5. SociallHealth magazines & 92.4 & 83.6 & .080 \\
\hline 6. Posters and pamphiets & 88.2 & 86.4 & .093 \\
\hline 7. Health care provider & 86.8 & 86.6 & $.255^{* *}$ \\
\hline 8. Been given free condoms & 79.5 & 86.6 & $.280^{* *}$ \\
\hline 9. Other people & 91.5 & 74.2 & .094 \\
\hline 10. Socialireligious organisations & 63.8 & 75.4 & $.330^{* *}$ \\
\hline 11. Counselling & 52.9 & 61.2 & $.190^{*}$ \\
\hline 12. No information & 42.5 & 58.2 & $-220^{*}$ \\
\hline
\end{tabular}

\section{AIDS health beliefs}

Table 4 indicates AIDS health beliefs among the participants by gender.

Table 4: AIDS health beliefs by gender and means (from $1=$ strongly disagree to $6=$ strongly agree)

\begin{tabular}{|c|c|c|c|}
\hline \multirow[t]{2}{*}{ llems } & Male & Female & T-Test \\
\hline & $M(S D)$ & $M(S D)$ & $F$ \\
\hline Perceived susceptibllity & $3.4(1.8)$ & $3.5(1.8)$ & 3.643 \\
\hline $\begin{array}{l}1.1 \text { teet that the chances are good that I can get } \\
\text { AlDS }\end{array}$ & $3.1(1.9)$ & $3.3(2.0)$ & -.825 \\
\hline 2. I am afraid that 1 might contract AlDS & $3.8(1.7)$ & $3.6(1.8)$ & .713 \\
\hline $\begin{array}{l}\text { 3. I believe that I can be exposed to HIV } \\
\text { infection if my sex partner is heterosexual }\end{array}$ & $3.5(19)$ & $3.7(1.8)$ & -661 \\
\hline $\begin{array}{l}\text { 4. I believe that I can get ADS even if I only } \\
\text { have sex with one partner }\end{array}$ & $3.0(1.8)$ & $3.9(1.7)$ & $-3.050^{*+}$ \\
\hline Parceived severity & $3.8(1.9)$ & $4.1(1.6)$ & .377 \\
\hline 5. AIDS causes death & $4.1(2.0)$ & $4.0(1.5)$ & .133 \\
\hline $\begin{array}{l}\text { 6. Twould rather have any other temtinal illness } \\
\text { than AlDS }\end{array}$ & $3.6(1.6)$ & $3.9(1.8)$ & -1149 \\
\hline $\begin{array}{l}\text { 7. Wwoud rather die from a violent death (e.g. } \\
\text { gunshot, car accident, atc.) than from AlDS }\end{array}$ & $4.0(1.8)$ & $4.0(1,6)$ & .023 \\
\hline $\begin{array}{l}\text { 3. Alds is probaby the worst disease a person } \\
\text { can get }\end{array}$ & $3.8(1.9)$ & $4.1,1.5\}$ & -1.192 \\
\hline Perceived benefits & $3.6(1.8)$ & $3.6[1.7)$ & .365 \\
\hline $\begin{array}{l}\text { 9. I believe that the chances of contracting ADS } \\
\text { can be signiticanty reduced by using a concom }\end{array}$ & $3.5(1.9)$ & $3.2(1.8)$ & 1,142 \\
\hline $\begin{array}{l}\text { 10. I think it is worth the effort to have condons } \\
\text { readily avalybte }\end{array}$ & $3.6(1.8\}$ & $34(3.5)$ & .751 \\
\hline $\begin{array}{l}\text { 11. Peet that the chences of contracting Alos } \\
\text { can be recuced by hewing sex with onivo one } \\
\text { partner }\end{array}$ & $4.0(1.8)$ & $3.9(1.5$ & .213 \\
\hline 12. If a condon is not avaliable, it would be & $3.6(1.7)$ & $3.8(1.6)$ & -1.048 \\
\hline
\end{tabular}




\begin{tabular}{|c|c|c|c|}
\hline $\begin{array}{l}\text { Worth the effort to discontinue sexual activity to } \\
\text { obtain a condom }\end{array}$ & & & \\
\hline Perceived bartiers & $3.6(1.8)$ & $4.0(1.6)$ & .817 \\
\hline $\begin{array}{l}\text { 13. Using a condom seems like an insult to my } \\
\text { partner }\end{array}$ & $3.5(1.8)$ & $4.1(1.7)$ & $-2.098^{\circ}$ \\
\hline 14. It is embarrassing (to me) to bur condoms & $3.2(1.7)$ & $4.1(1.5)$ & $-3.361 * * 2$ \\
\hline $\begin{array}{l}\text { 15. I do not enjoy (or think I might not enjoy) sex } \\
\text { when using a condom }\end{array}$ & $3.9(1.8)$ & $4.0(1.6)$ & -.587 \\
\hline $\begin{array}{l}\text { 16. I would offer first-aid to an AIDS patient } \\
\text { because I would feel guilty for not offering help }\end{array}$ & $3.8(1.7)$ & $3.9(1.7)$ & 1.038 \\
\hline
\end{tabular}

High mean rates of the Health Belief were found on each sub-scale of the AIDS Health Belief Scale, from 3.9 for perceived severity, 3.8 for perceived barriers, 3.6 for perceived benefits and 3.5 for perceived susceptibility in that order of importance. There were no gender significant differences with regard to each sub-scale. However, it is significant to note that females found it more embarrassing to buy condoms, had a higher belief that one can contract AIDS even if they had only one sex partner and found it more insulting to use a condom with a partner than males did.

\section{Condom use self-efficacy}

Table 5 indicates self-efficacy of condom use by gender.

Table 5: Self-efficacy of condom use by gender ( $0=$ strongly disagree to $4=$ strongly agree)

\begin{tabular}{|c|c|c|c|}
\hline & Male & Female & Trfest \\
\hline Statements (abbreviated) & $M(S D)$ & $M(S D)$ & $F$ \\
\hline 1. Confident to put on a condom & $2.4(1.4\}$ & $1.7(1.5)$ & .632 \\
\hline 2. Conficient to purchase condoms & $2.2(1.4)$ & $1.8(1,2)$ & 2.783 \\
\hline 3. Conficent to carry a condom & $2.7(1.3\}$ & $2.1(1.3)$ & .094 \\
\hline 4. Confident to discuss condom usage & $3.0(1.3)$ & $2.1(1.3)$ & .002 \\
\hline 5. Confident to suggest using condoms & $2.6(1.1)$ & $2.1(1.2)$ & 7.045 \\
\hline $\begin{array}{l}\text { 6. Confident to suggest using a condom without my partiner } \\
\text { feeling "diseased" }\end{array}$ & $2.6\{1.3\}$ & $2.7(1.4)$ & .759 \\
\hline 7. Contident to maintain an erection while using a condom & $26(1,2)$ & $2,1(1,1)$ & $4.941^{\circ}$ \\
\hline 8. Feeling embarrassed to put a condom on -3 & $1.7(1.3)$ & $2.4(1.3)$ & .072 \\
\hline (3) Afraid of rejection when suggesting condom use 3 & $1.9(1.4)$ & $2.2(1.3)$ & .208 \\
\hline $\begin{array}{l}\text { 10. Not suggesting concem use when unsure about partrer's } \\
\text { view on condoms } 0\end{array}$ & $2.3(1.4)$ & $1,8(1,4)$ & .277 \\
\hline 11. Confident to use a condom correcly & $2.4(1,2)$ & $2.4(1.4)$ & 1.630 \\
\hline $\begin{array}{l}\text { 12. Comborable discussing condom use with new pantre befote } \\
\text { icuching }\end{array}$ & $28(1,1)$ & $1.9(1.1\}$ & .907 \\
\hline 13. Confident to persuade a parther to accapt using a condom & $2.3(1.1)$ & $2.5\{1.2\}$ & $3923^{\circ}$ \\
\hline $\begin{array}{l}\text { 14. Configent to temove and dispose of a condom after sexual } \\
\text { intercourse }\end{array}$ & $2.4(1,5)$ & $2.4(1.5)$ & .471 \\
\hline $\begin{array}{l}\text { 15. if my parther and i ware to try to us a condom and did not } \\
\text { succeed, I would teel embarrassed to try to use one again } 0\end{array}$ & $2.0(1.4)$ & $1.7(1.3)$ & 1.383 \\
\hline $\begin{array}{l}\text { 16. Not conticent siggesting condom use with new parther } \\
\text { since the latter thought I had homosexual experience s }\end{array}$ & $2.2(2.1)$ & $1.7(1.2)$ & $6.855^{n+}$ \\
\hline $\begin{array}{l}\text { 17. Not conticent suggesting condom use with new parthe? } \\
\text { since the !atter woutd have thought I had a STO (s) }\end{array}$ & $1.0(1.5)$ & $1.7(1.2)$ & $16.937^{\cdots \cdots}$ \\
\hline 18. Nal conficent suggesting condom use with new parther & $20(1,4)$ & $2.2\{1.4\}$ & $.14 !$ \\
\hline
\end{tabular}

\begin{tabular}{|c|c|c|c|}
\hline since I would have thought the latter had a STD 8 & & & \\
\hline $\begin{array}{l}\text { 19. Comfortable discussing condom use with new partner before } \\
\text { intercourse }\end{array}$ & $2.6(1.4)$ & $2.3(1.5)$ & 220 \\
\hline 20. Confident to use condom as part of foreplay & $2.3(1.4)$ & $2.2(1.5)$ & .560 \\
\hline 21. Confident to use condom without 'oreaking the mood' & $2.8(1.2)$ & $2.6(1.3)$ & $9.705^{\circ *}$ \\
\hline 22. Conficent to use condom on myself of parther quickly & $2.6(1.3)$ & $2.3(1.1)$ & 3.547 \\
\hline $\begin{array}{l}\text { 23. Confident to use corrom without reducing sexual } \\
\text { sensations }\end{array}$ & $2.6(1.1)$ & $1.9(1.3)$ & 1.897 \\
\hline 24. Confident to use condom after drinking & $2.4(1.3)$ & $1.9(1.2)$ & $4.184^{\circ}$ \\
\hline 25. Confident to use condom even if / were high & $2.4(1.4)$ & $2.2(1.2)$ & $7.452^{* *}$ \\
\hline 26. Could easily convince partner to use condom & $2.2(1.3)$ & $2.3(1.3)$ & 1.563 \\
\hline 27. Confident to use condom successfully & $2.8(1.2)$ & $2.4(1.2)$ & .151 \\
\hline 28. Confident to put on a condom in the heal of passion & $2.4(1.3)$ & $2.4(1.2)$ & 974 \\
\hline
\end{tabular}

High self-efficacy of condom use was found with the following: (i) confident to use condom successfully (2.6), (ii) confident to use condom without 'breaking the mood' (2.6), (iii) confident to suggest using condoms (2.5), and (iv) confident to use a condom quickly (2.5), and low self-efficacy with the following four: (i) "Not confident suggesting condom use with new partner since the latter would have thought I had a STD' (1.7), (ii) if my partner and I were to use a condom and did not succeed, I would feel embarrassed to try to use one again (1.9), (iii) not suggesting condom use with new partner since the latter would have thought I had a homosexual experience (2.0), and (iv) confident to purchase condoms (2.0). There were significant gender differences for 7 items indicating that females had lower self-efficacy than males, e.g. "Not confident suggesting condom use with new partner since the latter thought I had a STD", "Confident to use a condom without breaking the mood", "Confident to use a condom even if I were high" and "Not suggesting condom use with new partner since the latter thought I had a homosexual experience."

\section{Correlates of condom use}

Table 6 indicates the Pearson Correlation Coefficients for condom use, self-efficacy and intention to use condoms.

Age, gender, know someone with HIV/AIDS, and perceived HIV/AIDS severity was strongly related with lifetime condom use. Age, number of lifetime sex partners, perceived severity and prevention barriers of HIV/AIDS were strongly associated with condom use with last partner. Perceived susceptibility, prevention benefits and barriers of HIV/AIDS (three of four subscales) were strongly related to self-efficacy in condom use. Finally, age, number of lifetime sex partners, attitudes towards use of condoms and subjective as well as normative beliefs were positively associated with condom use intention

Multiple Stepwise Regression for the Theory of Reasoned Action found that subjective norms about condoms predicted condom use intention [Beta: .371; 
Table 6: Correlates of condom use, self-efficacy and intention to use condoms

\begin{tabular}{|c|c|c|c|c|}
\hline Variable & $\begin{array}{l}\text { Lifetime } \\
\text { condom use }\end{array}$ & $\begin{array}{l}\text { Condom use } \\
\text { with last } \\
\text { partner }\end{array}$ & $\begin{array}{l}\text { Self-eficacy in } \\
\text { condom use }\end{array}$ & $\begin{array}{l}\text { Condom use } \\
\text { intention }\end{array}$ \\
\hline Age & $215^{\circ}$ & $.230^{*+}$ & .064 & $.229^{*}$ \\
\hline Gender & $.318^{* *}$ & .118 & -.223 & .033 \\
\hline History of STD & .125 & .128 & .033 & .030 \\
\hline $\begin{array}{l}\text { Know someone with } \\
\text { HIVIAIDS }\end{array}$ & $.221^{* *}$ & .050 & -.082 & .004 \\
\hline $\begin{array}{l}\text { No. of lifetime sex } \\
\text { partners }\end{array}$ & .025 & $.348^{* * * 4}$ & .105 & $.429^{44+}$ \\
\hline $\begin{array}{l}\text { Behavioural norm to use } \\
\text { condoms }\end{array}$ & $.212^{*}$ & .053 & -139 & .080 \\
\hline $\begin{array}{l}\text { Attitudes towards use of } \\
\text { condoms }\end{array}$ & .006 & .044 & .082 & $.330^{* *}$ \\
\hline $\begin{array}{l}\text { Normative beliefs to use } \\
\text { condorns }\end{array}$ & .095 & .076 & $.205^{*}$ & $.227^{\circ}$ \\
\hline $\begin{array}{l}\text { Subjective norm to use } \\
\text { condoms }\end{array}$ & $.178^{*}$ & $208^{*}$ & $-419^{* 4}$ & $.338^{* 2}$ \\
\hline $\begin{array}{l}\text { Correct condom } \\
\text { knowledge }\end{array}$ & -.156 & .101 & .102 & $-.234^{* 4}$ \\
\hline $\begin{array}{l}\text { Perceived HIV/AIDS } \\
\text { susceptibility }\end{array}$ & .056 & .072 & $.452^{* *}$ & 150 \\
\hline $\begin{array}{l}\text { Perceived HIV/AIDS } \\
\text { severity }\end{array}$ & $368^{* *}$ & $.416^{* *}$ & .190 &,- 080 \\
\hline $\begin{array}{l}\text { Perceived HIV/AIDS } \\
\text { prevention benefits }\end{array}$ & $210^{\circ}$ & $.221^{*}$ & $.392^{2+}$ & -.121 \\
\hline $\begin{array}{l}\text { Perceived HIVIAIDS } \\
\text { prevention barriers }\end{array}$ & $211^{2}$ & $.326^{* *}$ & $.316^{+4}$ & -.081 \\
\hline Condom use seff-efficacy & .020 & -048 & $+\cdots$ & .004 \\
\hline
\end{tabular}

$\left.\mathrm{t}=4.471^{* * *}\right]$ and Multiple Stepwise Regression for the AIDS Health Belief Model indicated that only AIDS susceptibility predicted lifetime condom use [Beta: $.423 ; \mathrm{t}=4223^{* * *}$ ] and condom self-efficacy [Beta: .628; $\left.\mathrm{t}=6.510^{* * *}\right]$.

\section{DISCUSSION}

One year after puberty both males $(\mathrm{M}=14.9$ years $)$ and females ( $M=15.6$ years) in this sample had engaged in sex. Buga, Amoko and Ncayiyana (1996:96) found among school girls in the Eastern Cape, South Africa, that their mean age at first coitus was $14.86(\mathrm{SD}=1.81)$. Significant to note is that about half of the sexually active sample $(52.6 \%$ males and $40.5 \%$ females $)$ reported never having used condoms. Among Tanzanian sexually active school pupils ( $M$ age 17 years) $21.5 \%$ reported to have used condoms at their most recent sexual intercourse (Lugoe \& Biswalo, 1997:74). OfEthiopian students (mean age 14.74 years) $19.5 \%$ admitted to having had coital experience at least once in their life. The mean age of onset of sexual intercourse for girls was 15.30 years and for boys 16.45 years. Only $43.2 \%$ knew about condoms on their first coital encounter. Eighty two percent did not use condoms on their first sexual encounter (Eshetu, Zakus $\&$ Kebede, 1997:9). Similarly, Matasha, Ntembelea and
Mayaud (1998:571) also found high rates of sexually active boys $(80 \%)$ and girls $(68 \%)$ in primary schools and the corresponding figures were $89 \%$ for boys and $48 \%$ for girls in secondary schools in Tanzania. Despite a rather high (30\%) lifetime rate of condom use, 33\% and $25 \%$ of primary school boys and girls, respectively, reported past experience of sexually transmitted diseases. Bandawe and Foster (1996:226) found among Malawian secondary school pupils (mean age for females 17.87 and for males 19.23 years) that $60 \%$ of the sexually active claimed to have used (or their partners use) condoms. Females reported higher incidence of condom use by their partners $(70 \%)$ than males (52\%). Stanton, Fitzgerald, Li et al. (1999:132) found among Namibian youth (12-18 years) that over one third of these youth had had more than one sexual partner in the previous 6 months and over half had not used a condom at the last episode of intercourse. Thus there is considerable scope for improving rates of heterosexual condom use.

The overall knowledge about correct condom use was high (but significantly lower for females) in this sample. In a study of an urban adult community in South Africa similar levels of correct but also false condom knowledge was found (Peltzer, 2000).

Most participants had multiple access to 'condom' information via various channels. Interesting to note is although radio, television and education talks were the most common media for condom information, correct condom use knowledge was associated with the following sources of 'condom' information: social/religious organisation, health care provider, posters and pamphlets and counseling, in that order. Thus, it seems relevant to underline the latter 'condom' information providers and place emphasis on them (also in regard to gender specificity) in HIV (condom) health promotion.

High mean rates of the Health Belief were found on each sub-scale of the AIDS Health Belief Scale, from 3.9 for perceived severity, 3.8 for perceived barriers, 3.6 for perceived benefits and 3.5 for perceived susceptibility in that order of importance. The AIDS Health Belief scale was related to past and current condom use as well as to self-efficacy in condom but not with condom use intentions. AIDS susceptibility was found to be predictive for lifetime condom use and self-efficacy to use condoms. Therefore the utility of the Health Belief Model could only be partially confirmed for condom use parameters (Brafford \& Beck, 1991:219; Lollis, Johnson \& Antoni, 1997:555f.).

The factors of HIV preventive behaviour identified should be considered in the development of an educational or intervention programme. Specifically, such programmes should include components on the susceptibility that individuals have to HIV infection. In 
this study participants scored very high on the AIDS Health Belief sub-scale 'perceived severity' indicating great concern about HIV. Research has shown that the more concerned individuals are about becoming infected, the more likely they are to engage in safer HIV-related behaviours. In addition, the benefit of engaging in safer behaviour must be emphasised and that perceived barriers to preventive behaviour are possible to overcome (Boyd \& Wandersman, 1991:1810).

Self-efficacy of condom use was unlike in some studies (Basen-Engquist, 1992:122; Brafford and Beck, 1991:222) not related to past, current and future condom use. Therefore, self-efficacy of condom use should be improved, e.g. suggesting condom use with new partner or the purchase of condoms. Examining the responses to the individual items on the Condom Use Self-Efficacy Scale could help identify behaviours which cause discomfort (or are anticipated as being uncomfortable) for an individual who does not consistently use condoms. A health educator could then focus on appropriate skills in discussing condom use with a partner. From the correlations from this study on condom use the following items seem to be particularly relevant for condom promotion: "use condom successfully', 'use of condom without breaking the mood', or 'use a condom quickly'. Regarding low selfefficacy items the following are particularly important to address: "suggest (persuade, convince) using condoms (with a new partner)'and 'purchase of condoms'. Addressing these areas of low self-efficacy health educators could - depending on age and gender focus on interpersonal skills in discussing condom use with a partner, physically handling a condom, talking through the embarrassment of using a condom, or perhaps building assertiveness skills (Brafford and Beck, 1991:224).

\section{RECOMMENDATIONS}

The study found a lack of heterosexual condom use and some lack of correct condom use knowledge (especially among females), which needs to be addressed in programmes for improving rates of heterosexual and correct condom use.

There is a need for some forms of media such as radio, television and education talks to improve their presentation in order to improve the knowledge of correct condom use. Health education agents such as social/religious organisations, health care providers, posters and pamphlets and counseling as sources of 'condom' information can be emphasised more due to their effectiveness in imparting correct condom use knowledge.

The factors of HIV preventive behaviour such as components of the susceptibility that individuals have to HIV infection, the perceived severity of HIV/AIDS indicating great concern about HIV, and the benefit of engaging in safer behaviour must be emphasised and that perceived barriers to preventive behaviour are possible to overcome should inform the development of an educational or intervention programme.

Self-efficacy of condom use should be improved, e.g. suggesting condom use with new partner or the purchase of condoms. Health education should focus on appropriate skills in discussing condom use with a partner considering age and gender differences.

\section{Acknowledgements}

I thank the University of the North for the financial support to conduct the study.

\section{REFERENCES}

Abraham, SCS; Rubaale, TK \& Kipp, W 1995: HIV preventive cognitions amongst secondary school students in Uganda. Health Education Research, 10, 1995:155-162.

Abraham, CS; Sheeran, P; Abrams, D \& Spears, R 1996: Health beliefs and teenage condom use: a prospective study. Psychology and Health, 11, 1996:641-655.

Bandawe, CR \& Foster, D 1996: AIDS-related beliefs, attitudes and intentions among Malawian students in three secondary schools. AIDS CARE, 8, 1996:223232.

Basen-Engquist, K 1992: Psychosocial predictors of "safer sex" behaviours in young adults. AIDS Education Prevention, 4, 1992:120-134.

Boyd, B \& Wandersman, A 1991: Predicting undergraduate condom use with the Fishbein and Aizen and the Triandis Attitude-Behaviour models: implications for public health interventions. Journal of Applied Social Psychology, 21, 1991:1810-1830.

Brafford, LJ \& Beck, KH 1991: Development and validation of a Condom Self-Efficacy Scale for College students. Journal of American College Health, 39, 1991:219-225.

Buga, GAB; Amoko, DHA \& Ncayiyana, DJ 1996: Adolescent sexual behaviour, knowledge and attitudes to sexuality among schoolgirls in Transkei, South Africa. East African Medical Journal, 73, 1996:95100.

Campbell, T 1997: How can psychological theory help promote condom use in sub-Saharan African developing countries. Journal of the Royal Society for Health, 117, 1997:186-191.

Edem, CU \& Harvey, SM 1994/95: Use of Health Belief 
Model to predict condom use among university students in Nigeria. International Quarterly of Community Health Education, 15, 1994/1995:3-14.

Eshetu, F; Zakus, D \& Kebede, D 1997: The attitudes of students, parents and teachers towards the promotion and provision of condoms for adolescents in Addis Ababa. Ethiopian Journal of Health \& Development, 11, 1997:7-16.

Gould, P 1993: The slow plague. London: Blackwell.

Harvey, SM; Beckman, LJ \& Wright, C 1996/97: Perceptions and use of the male condom among African American University students. International Quarterly of Community Health Education, 16, 1996/1997:139-153.

Kidan, KG \& Azeze, B 1995: Survey of condom use among college students. Ethiopian Journal of Health \& Development, 9, 1995:7-11.

Lollis, CM; Johnson, EH \& Antoni, MH 1997: The efficacy of the health belief model for predicting condom usage and risky sexual practices in University students. AIDS Education \& Prevention, 9, 1997:551-563.

Lugoe, WL \& Biswalo, PM 1997: Self-restraining and condom use behaviours: the HIV/AIDS prevention challenges in Tanzanian schools. International Journal of Adolescence and Youth, 7, 1997:67-81.

Lule, GS \& Gruer, LD 1991: Sexual behaviour and use of condom among Ugandan students. AIDS CARE, 3 , 1991:11-19.

Manderson, L; Tye, LC \& Rajanayagam, K 1997: Condom use in heterosexual sex: a review of research, 1985-1994. (In: J Catalan; L Sherr et al. (eds.) The impact of AIDS: psychological and social aspects of HIV infection. Singapore: Harwood Academic Publishers.pp. 1-26.)

Matasha, E; Ntembelea, T; Mayaud, P; Saidi, W; Todd, J; Mujaya, B \& Tendo-Wambua, L 1998: Sexual and reproductive health among primary and secondary school pupils in Manza, Tanzania: need for intervention. AIDS CARE, 10, 1998:571-582.

Peltzer, K 2000: Knowledge and practice of condom use in an urban adult community sample of the Northern Province, South Africa. Health SA Gesondheid, 5(1), 2000:38-44.

Sindiga, I \& Luhando, M 1993: Kenyan university students' views on AIDS. East African Medical Journal, 70, 1993:713-716.
Condoms: mis-use $=$ non-use. The condom equation in Gujarat, India. AIDS CARE, 9, 1997:707-713.

Stanton, BF; Fitzgerald, AM; Li, X; Shipena, H; Ricardo, IB; Galbraith, JS; Terreri, N; Strijdom, J; Hangula-Ndlovu, V \& Kahihuata, J 1999: HIV risk behaviours, intentions, and perceptions among Namibian Youth as assessed by a theory-based questionnaire. AIDS Education \& Prevention, 11, 1999:132-149.

Webb, D 1997: HIV and AIDS in Africa. Cape Town: David Philip.

World Health Organisation 1990: Global programme on AIDS: orientation manual: condom and virucide services. Geneva: author.

World Health Organisation 1995: Condom promotion for AIDS prevention. Geneva: author.

Zagumny, MJ \& Brady, DB 1998: Development of the AIDS Health Belief Scale (AHBS). AIDS Education \& Prevention, 10, 1998:173-179.

Sharma, V; Dave, S; Sharma, A \& Chauhan, P 1997: 